\title{
DNA Wildlife Forensics: Present and Future
}

\section{Sandeep Kumar Gupta*}

Wildlife Institute of India, Chandrabani, Dehradun, India

\begin{abstract}
Wildlife crime investigation is one of the important facets of forensics science. DNA typing is one of the effective protocols for dealing such issues. The availability of conserved and universal primers has enormous scope in DNA wildlife forensics. These universal primers are designed based on the various conserved regions located on the genes of mitochondrial genome. This study explains the use of DNA typing and genetic profiling in dealing the wildlife crime cases.
\end{abstract}

Keywords: Wildlife crime investigation; DNA typing; Universal primers; Mitochondrial genome; Conserved regions; Genetic profiling

Illegal hunting of wildlife is a serious worldwide concern for wildlife management. The ornamental body part and other traditional uses of the body part of wildlife are the major challenge in control of wildlife poaching. Moreover, the effective identification of the species from available biological material is a key parameter in fixing the accurate wildlife offence. Hence, wildlife forensics is a vital branch of forensics, which deals with the identification of the species from biological remnant. This science has evolved very rapidly and has enormous scope in biodiversity conservation. When intact morphological feature are available in the seizer, the examination of the morphological character of the sized biological material is one of the rapid mode of the delivering the report. The comparison of hair morphometry [1-7] and morphological osteology [8] are the important scientific protocol for identification of the source of the origin of unknown sample. However, the morphological examination has some limitation while examining the sample of unknown animal species, when intact reference sample from known source are not available.

\section{DNA Typing}

DNA typing is one of the most effective protocols so far in dealing wildlife crime cases, which is the basis for the DNA wildlife forensics. The DNA typing composed of some basic steps including the DNA extraction, PCR amplification, DNA sequencing and sequence comparison. The genes located on mitochondrial DNA (mtDNA) are the source of most effective molecular marker used in wildlife forensics. The mtDNA inherited from mother to progeny and do not participate in crossing over. Hence, it is one of the pure forms of the DNA and has various conserve regions on its gene, which are the basis for selection of conserved of universal primers [9-11]. The use of universal primers minimise the effort of researcher, since it can be applied for PCR amplification to the DNA of all species without prior information of the victim species. The DNA sequence generated from the victim species can be compared with suitable data base to get the accurate identity of the source.

When the specific gender is preferred in poaching as in cases of Asian elephant, Elephas maximus, the gender specific markers are useful in identification of the gender of the decomposed or altered carcass in determining the cause of the death of individual [12].

\section{Success in DNA Typing}

The DNA typing has successfully applied in dealing the wildlife crime cases. It was helpful in identification of the trace biological material collected from wooden chopping block [13]. In this case accused tried to mislead the cope by providing the samples of domestic chicken (Gallus gallus), however; the crime was established by comparison of the DNA sequences generated from the biological remnant collected from chopping wood [13]. The victim species was identified as the Schedule-I protected animals the Pea fowl (Pavo cristatus).

In another case of wildlife crime, two idols were analysed for identification of the source of the origin [14]. The identification was confirmed by species specific markers developed for elephant [14] The comparison of DNA sequence confirmed that idols were derived from Asian elephant. Hence, species specific markers are also has its significance in wildlife forensics.

\section{Application of Individual Matching in Wildlife Forensics}

Individual profiling and matching is one of the worldwide common protocols in forensics. Individual profiling is done based on widely deployed microsatellite markers, where a panel of polymorphic markers are used in generating the individual's profile. The individual profile can be matched with the biological relatives. It has enormous potential in wildlife forensics too. When a tiger (Panthera tigris) was poached from Zoo Park the same has been proven an asset in forensic investigation [15]. The tiger was poached in the year 2000 and the remnant (claw) was found with accused in year 2005. There was no biological sample was made available from the deceased tiger. The genetic profile was generated from the claw along with the known biological relatives of the deceased tiger. The genetic matching confirmed that the claw belongs to the missing individual of the alleged family [15].

In another case of suspected wildfire crime, the individual matching has helped to wildlife manager in taking the proper decision. An elephant tusk was found in a reserve forest, which was collected

*Corresponding author: Sandeep Kumar Gupta, Wildlife Institute of India, Chandrabani, Dehradun, India, Tel: +91-135-2640111-15 (ext. 353); Fax: +91-1352640117; E-mail: skg@wii.gov.in

Received February 23, 2011; Accepted February 23, 2012; Published February 25,2012

Citation: Sandeep Kumar G (2012) DNA Wildlife Forensics: Present and Future. J Forensic Res 3:e103. doi:10.4172/2157-7145.1000e103

Copyright: (c) 2012 Sandeep Kumar G. This is an open-access article distributed under the terms of the Creative Commons Attribution License, which permits unrestricted use, distribution, and reproduction in any medium, provided the original author and source are credited. 
and stored by wildlife manager [16]. Subsequently, one carcass of a male elephant was found with one missing tusk. The small pieces of the ivory colleted from both the tusk were examined for individual matching. The genetic profiling based on polymorphic microsatellite loci confirmed that both the ivory samples are derived from the same individual. The examination report helped to wildlife manager in proper wildlife management [16].

\section{Scope in Wildlife Forensics}

The limiting factor in wildlife forensics is lack of strong data base for wildlife. There is a grave need to build the data base for the all range of the wild species. This includes the need of the research and development for strengthening gene bank of the endangered species.

\section{Acknowledgement}

Author acknowledges the support from Director and Dean, WII along with the nodal officer of the forensics cell at WII. The research of SKG is supported by the Ministry of Environment and Forest, Govt. of India through Grant-in-Aid to WII.

\section{References}

1. Mathiak HA (1938) A key to the hairs of mammals of southern Michigan. J Wild Manage 2: 251-268.

2. Mayer WVC (1952) The hair of Californian mammals with keys to the dorsa guard hairs of Californian mammals. Am Midl Nat 48: 480-512.

3. Hausman LA (1920) Structural characteristics of the hair of mammals. Am Nat 54: $496-526$

4. Brunner H, Coman B (1974) The identification of mammalian hair Shanghai Printing Press Ltd, Hong Kong.

5. Koppikar BR, Sabnis JH (1975) Identification of hairs of some Indian mammals.
J Bomb Nat Hist Soci 7: 35-20.

6. Chakraborty R, Chakraborty S, De JK (1999) Identification of dorsal guard hairs of the species of Indian lesser cats (Carnivora: Felidae) Mammalia 65: 93-104.

7. Bahuguna A, Mukherjee SK (2000) Use of SEM to recognise Tibetan antelope Chiru hair and blending in wool products. Sci Justice 40: 177-182.

8. Margaret ES, Barry WB, Robert MH (2011) Tusk or Bone? An Example of Ivory Substitute in the Wildlife Trade. Ethnobiology Letters 2: 40-44.

9. Kocher TD, Thomas WK, Meyer A, Edwards SV, Paabo S, et al. (1989) Dynamics of mitochondrial DNA evolution in animals: amplification and sequencing with conserved primers. Proc Natl Acad Sci USA 86: 6196-6200.

10. Parson W, Pegoraro K, Neiderstatter H, Foger M, Steinlechner M (2000) Species identification by means of cytochrome b gene. Int J Legal Med 114 23-28.

11. Verma SK, Singh L (2003) Novel universal primers establish identity of enormous number of animal species for forensic application. Mol Ecol Notes 3: 28-31.

12. Gupta SK, Thangaraj K, Singh L (2006) A Simple and Inexpensive Molecular Method for Sexing and Identification of the Forensic Samples of Elephant Origin. J Forensic Sci 51: 805-807.

13. Gupta SK, Verma SK, Singh L (2005) Molecular insight into a wildlife crime: the case of a peafowl slaughter. Forensic Sci Int 154: 214-217.

14. Gupta SK, Bhagavatula J, Thangaraj K, Singh L (2011) Establishing the identity of the massacred tigress in a case of wildlife crime. Forensic Sci Int Genet 5 : 74-75.

15. Gupta SK, Thangaraj K, Singh L (2011) Identification of the source of ivory ido by DNA analysis. J Forensic Sci 56: 1343-1345.

16. Gupta SK, Kumar A, Nigam P (2011) Multilocus Genotyping of Asian Elephan Ivory: A Case Study in Suspected Wildlife Crime. J Forensic Res S1: 002. 